IZA DP No. 4665

Income Support Systems, Labor Market Policies and Labor Supply: The German Experience

Marco Caliendo

December 2009 


\title{
Income Support Systems, Labor Market Policies and Labor Supply: The German Experience
}

\author{
Marco Caliendo
}

$I Z A$, DIW Berlin and IAB

\section{Discussion Paper No. 4665 \\ December 2009}

\author{
IZA \\ P.O. Box 7240 \\ 53072 Bonn \\ Germany \\ Phone: +49-228-3894-0 \\ Fax: +49-228-3894-180 \\ E-mail: iza@iza.org
}

Any opinions expressed here are those of the author(s) and not those of IZA. Research published in this series may include views on policy, but the institute itself takes no institutional policy positions.

The Institute for the Study of Labor (IZA) in Bonn is a local and virtual international research center and a place of communication between science, politics and business. IZA is an independent nonprofit organization supported by Deutsche Post Foundation. The center is associated with the University of Bonn and offers a stimulating research environment through its international network, workshops and conferences, data service, project support, research visits and doctoral program. IZA engages in (i) original and internationally competitive research in all fields of labor economics, (ii) development of policy concepts, and (iii) dissemination of research results and concepts to the interested public.

IZA Discussion Papers often represent preliminary work and are circulated to encourage discussion. Citation of such a paper should account for its provisional character. A revised version may be available directly from the author. 
IZA Discussion Paper No. 4665

December 2009

\section{ABSTRACT \\ Income Support Systems, Labor Market Policies and Labor Supply: The German Experience*}

In view of the demographic trends, most EU countries face the problem of a declining work force in the future. Understanding the interaction between income support systems (such as unemployment benefits, social assistance, early retirement and pension systems) and total labor supply is of crucial importance to combat problems and ensure economic growth in the future. The German labor market has been plagued by high and persistent unemployment in the last two decades in combination with a relatively low labor force participation of women. This created a situation where labor market reforms were unavoidable. The speed and depth of the reforms are remarkable, mainly aimed at activating people by increasing their incentives to take up work. The aim of this paper is to give a brief overview of the German income support systems and labor market polices, their recent reforms and - where already possible - effects of these reforms. Overall, Germany seems to be on the right track. The recent reforms helped to tackle some labor market problems but also created high political unrest. It remains to be seen how future governments react to worsened economic conditions in light of these experiences.

JEL Classification: J26, J38, J68

Keywords: unemployment, labor force participation, labor supply, benefit systems, public policy

Corresponding author:

Marco Caliendo

IZA

P.O. Box 7240

53072 Bonn

Germany

E-mail: caliendo@iza.org

\footnotetext{
* This paper has been prepared for the "EU High-Level Conference on Labour Market Inclusion" which took place in Stockholm from October 26-27, 2009, and has been presented in the session "International Seminar on Labour Market Inclusion" organized by IFAU, Uppsala.
} 


\section{Introduction}

The European Union (EU) currently suffers from a recession which results in an increase of long-term unemployment in most countries. In terms of demographic trends, however, a major problem of the EU is the declining number of people in working age. Early retirement is one of the main reasons that there are considerably less people in the work force than actually might be available, i.e., those of working age and capable of work. These non-employed are either unemployed or economically inactive. In this context, economically inactive is defined as neither being employed nor looking for a job. ${ }^{1}$ Understanding the interaction between income support systems (such as unemployment benefits, social assistance, early retirement and pension systems) and total labor supply is of crucial importance to combat potential problems and ensure economic growth in the future.

Independently of the current recession, the German labor market has been plagued by high and persistent unemployment in the last two decades. Since the end of the seventies, unemployment rates increased steadily and since the reunification in 1990 the unemployment rate rose from $7.3 \%$ to $13.0 \%$ in 2005 ; the situation in East Germany being especially troublesome with an unemployment rate of $20.6 \%$ in 2005 . Taken together with a relatively low female labor force participation, this created a situation where labor market reforms have been unavoidable. These reforms were initiated in 2001/2002 and the speed and depth of the reforms is quite remarkable. This is especially true when one keeps in mind that the German welfare state has been typically depicted as the prime example of the conservative welfare regime and being a "frozen welfare state" highly resistant to change (see, inter alia, Esping-Andersem, 1990; Manow and Seils, 2000; Kemmerling and Bruttel, 2005; Konle-Seidl, Eichhorst, and Grienberger-Zingerle, 2007).

The reforms touched the core elements of the labor market, including active and passive labor market policies, the organizational structure of the labor offices as well as the pension system. As a general goal, the reforms aimed at activating people by increasing their incentives to take up work. Additional efforts have been made to increase the labor force participation of young families. The aim of this paper is to give a brief overview of the German income support systems and labor market policies, their recent reforms and-where already possible - the effects of these reforms. The report is organized in the following way: in Section 2, we will discuss the employment and inactivity trends in Germany in light of the general

\footnotetext{
${ }^{1}$ See the report by Alphametrics/Applica (2009) for details.
} 
trends in the EU. Section 3 will describe the various relevant income support systems in Germany and outline the most recent reforms. In Section 4 we will summarize the already available evidence on the effects of these reforms before Section 5 concludes.

\section{Trends in Inactivity and Employment: Germany in the EU}

Based on the report by Alphametrics/Applica (2009) we discuss the most recent trends in inactivity and employment in Germany (in relation to the development in the EU). In 2008, around $66 \%$ of people in the working age (15 to 64 years) were employed in the EU-27, 29\% were classified as economically inactive and $5 \%$ as unemployed (see Table 1). ${ }^{2}$ In Germany, the overall employment (71\%) and unemployment $(6 \%)$ rates are slightly higher and correspondingly the share of inactive people is lower at $23 \%$. There are substantial gender differences, with an inactivity rate of $18 \%$ for men and $29 \%$ for women. The share of inactive females in the prime working age (25-49 years) is roughly $20 \%$ in Germany which is slightly higher than in the EU. One of the reforms we will discuss later on - the parental leave benefit (PLB, Elterngeld) — was designed in order to tackle this problem. Any tendency towards early retirement can be explored in more detail by examining developments in non-employment rates among older workers. In 2008, the non-employment rate added up to $70 \%$ for those aged 60-64 in the EU as a whole. In recent years, however, a common tendency towards a decline of the non-employment rate was observed for the EU-15 member states. Among individuals aged 55-59, the non-employment rate has declined from $48 \%$ in 2000 to $41 \%$ in 2008 , while it has been a stronger decrease for women than for men (Alphametrics/Applica, 2009). In Germany, the share of inactive males and females in the age group 55-59 is substantially lower at $31 \%$. This is also true for individuals aged 60-64 where the non-employment rate in Germany is only $65 \%$ compared to $70 \%$ in the EU. The German non-employment rate in this age group is also declining in most recent years which can be seen as a reaction to the efforts to raise the actual retirement age which we will discuss in Section 3.2.

\footnotetext{
${ }^{2}$ The employment rate is taken from the EU Labor Force Survey and is calculated by dividing the number of persons aged 15 to 64 in employment by the total population of the same age group. The survey covers the entire population living in private households and excludes those in collective households such as boarding houses, halls of residence and hospitals. The employed population consists of those persons who - during the reference week - did any work for pay or profit for at least one hour, or were not working but had jobs from which they were temporarily absent.
} 
Table 1: Trends in Inactivity and Employment: Selected Statistics for Germany and the EU (in\%)

\begin{tabular}{|c|c|c|c|c|c|c|}
\hline \multirow[t]{2}{*}{ Statistic } & \multicolumn{3}{|c|}{ Germany } & \multicolumn{3}{|c|}{ EU-27 } \\
\hline & Total & Men & Women & Total & Men & Women \\
\hline \multicolumn{7}{|l|}{ Activity status (15-64) in 2008} \\
\hline Employed & 70.7 & 75.9 & 65.4 & 65.9 & 72.8 & 59.1 \\
\hline Unemployed & 5.8 & 6.2 & 5.4 & 5.0 & 5.2 & 4.8 \\
\hline Inactive & 23.5 & 17.9 & 29.2 & 29.9 & 22.0 & 36.1 \\
\hline $\begin{array}{l}\text { Non-employment rates of men and } \\
\text { women by age }(2008)\end{array}$ & & & & & & \\
\hline $15-64$ & 29.3 & 24.1 & 34.6 & 34.1 & 27.2 & 40.9 \\
\hline $55-59$ & 31.1 & 23.3 & 38.6 & 41.0 & 31.3 & 50.2 \\
\hline $60-64$ & 64.9 & 56.7 & 72.7 & 69.8 & 61.1 & 77.9 \\
\hline \multirow{2}{*}{\multicolumn{7}{|c|}{$\begin{array}{l}\text { Activity rates by highest education level } \\
\text { attained in } \mathbf{2 0 0 8}(\mathbf{2 5 - 6 4 )} \\
\text { High education (ISCED level 5-6) }\end{array}$}} \\
\hline & & & & & & \\
\hline Employment rate & 86.6 & 89.5 & 82.7 & 85.3 & 89 & 81.8 \\
\hline Unemployment rate & 3.2 & 2.9 & 3.8 & 3.4 & 3.0 & 3.9 \\
\hline Inactivity rate & 10.2 & 7.8 & 14.1 & 11.7 & 8.3 & 15.0 \\
\hline \multicolumn{7}{|l|}{ Medium Education (ISCED level 3-4) } \\
\hline Employment rate & 76.1 & 81.1 & 71.2 & 74.9 & 81.5 & 67.9 \\
\hline Unemployment rate & 7.1 & 7.1 & 7.1 & 5.6 & 5.0 & 6.3 \\
\hline Inactivity rate & 18.1 & 12.6 & 23.4 & 20.6 & 14.1 & 27.5 \\
\hline \multicolumn{7}{|l|}{ Low Education (ISCED level 0-2) } \\
\hline Employment rate & 55.6 & 66.5 & 48.2 & 56.6 & 69.8 & 44.6 \\
\hline Unemployment rate & 16.2 & 17.8 & 14.7 & 9.8 & 9.0 & 10.8 \\
\hline Inactivity rate & 28.3 & 15.7 & 37.1 & 33.6 & 21.2 & 44.6 \\
\hline \multicolumn{7}{|l|}{$\begin{array}{l}\text { Reasons for not working among men and } \\
\text { women aged 15-64 (2007) }\end{array}$} \\
\hline of own illness or disability & 8.1 & 9.9 & 7.1 & 13.0 & 16.8 & 10.7 \\
\hline of other personal or family responsibilities & 18.8 & 1.3 & 29.5 & 17.8 & 2.2 & 27.3 \\
\hline of education or training & 38.5 & 51.7 & 30.4 & 31.2 & 40.5 & 25.5 \\
\hline of retirement & 25.6 & 31.2 & 22.2 & 21.6 & 26.5 & 18.6 \\
\hline of belief that no work is available & 1.1 & 0.9 & 1.3 & 4.0 & 3.7 & 4.1 \\
\hline of other reasons & 7.9 & 5.0 & 9.6 & 12.1 & 9.9 & 13.5 \\
\hline
\end{tabular}

Source: Eurostat, LFS and Alphametrics/Applica (2009)

Due to the association between education and employment prospects, we will also look at the inactivity levels differentiated by educational attainment. In the EU-27, a disproportionate high number of economically inactive individuals have relatively low education levels; which is especially true for women. In 2008, $46 \%$ of all economically inactive people (aged 25-64) in the EU had no educational qualification above basic schooling, i.e., education above level 2 of the International Standard Classification of Education (ISCED), which in turn corresponds to lower secondary education (6 years in nearly all EU member states). Table 1 also shows unemployment rates by education level. Whereas the unemployment rate is nearly $10 \%$ for individuals with low education (ISCED level $0-2$ ), it is only $6 \%$ for individuals with medium education (ISCED level 3-4) and even only $3.4 \%$ for high-skilled individuals (ISCED level 5-6). These figures are quite different for Germany: the unemployment rate for individuals with low education is $16 \%$ and therefore five times larger compared to highly educated individuals $(3.2 \%)$. Hence, low educated people in Germany face a 
much higher risk of joblessness than in other European countries. Therefore, some of the recent labor market reforms explicitly aim to increase labor force participation of lower educated individuals, e.g., by subsidizing social security contributions. We will discuss this in more detail in Section 3.3.

The Europan LFS also provides insights about the reasons why men and women across the EU are economically inactive. To be more specific: those who are neither employed nor unemployed in the reference week are asked to indicate the main reason for their inactivity status. A significant share of working age individuals were inactive because of being in education or training (31\%). Another relatively large share was inactive due to early retirement $(22 \%)$. Both shares are higher in Germany where $39 \%$ of the individuals aged 15-64 years state education as the main reason. This is due to the comparatively long schooling and vocational education system in Germany. But also early retirement is reported by $26 \%$. We will discuss the implications of this development for the pension system in Section 3.2. It is also interesting to look at individuals aged 25-49 years stating that family responsibilities kept them inactive (Alphametrics/Applica, 2009). Once again, Germany is an outlier with $53 \%$ of all inactive individuals in this age group and $67 \%$ of women reporting this as the main reason. The EU averages are $44 \%$ and $57 \%$ and for females in Denmark and Sweden the shares are even only $10 \%$ and $13 \%$. Clearly, one of the reasons for the disproportional rate in Germany is the problematic child-care situation. On average, child-care facilities allowing parents to work full-time exist only for $8 \%$ of the children under three years. We will discuss one initiative to overcome this in Section 3.4. Another possible reason lies in the current tax and social welfare legislation which favors the single male bread-winner model. We will briefly address this issue in Section 3.5.

\section{Institutional Setting and Recent Reforms in Ger- many}

In this section we will discuss the three most relevant income support systems in Germany. We will start with unemployment benefits and social assistance in Section 3.1 before we move on to pensions and sickness/disability insurance in Section 3.2. Since the most recent labor market reforms also changed active labor market policies towards an emphasis on activation measures, we will discuss these issues briefly, too, in Section 3.3. The new parental leave benefit scheme will be presented in Section 
3.4, before we will also address the effects of the German tax system on labor supply incentives in Section 3.5.

Before we do so, we will briefly sketch the political and economic situation leading to the labor market reforms in 2002. Many European countries had to face high unemployment rates in the 1990s, but Germany has especially proven to be unable to benefit from favorable conditions in the global economy. With only $18 \%$ the GDP growth rate between 1991 and 2003 was only half of the growth rate in the UK leading to decreasing employment and increasing unemployment (Jacobi and Kluve, 2007). Germany's tardy response to the worsening labor market situation can only be explained by a long period of reform blockage and postponement in labor market policy adjustments ( "Reformstau", see, e.g., Eichhorst and Marx, 2009). Certainly, the reunification in 1990 played a major role, where active labor market policies (and passive income support systems like early retirement) were used to take "surplus labor" out of the labor market. A clear indication of this is that in 1992 the number of participants in job creation schemes and training programs exceeded the number of unemployed in East Germany. Since deficits in the unemployment insurance schemes and the budget of the Federal Employment Agency (FEA) were covered by the federal government or higher contributions, this resulted in rising non-wage labor costs which in turn hampered employment creation (Konle-Seidl, Eichhorst, and Grienberger-Zingerle, 2007). The left-wing coalition in power since 1998 was torn between stabilizing the traditional "German social policy" approach and introducing the concept of a "activating state" in New Labour style. When the FEA was accused of massive fraud in reporting successful job placements in 2002, the government took advantage of this scandal and introduced some rather radical changes in German labor market policy. An independent expert commission worked out the blueprint for the reform package which is known as the Hartz reforms ${ }^{3}$, consisting of four laws (Hartz I-IV) implemented step by step between January 1, 2003 and January 1, 2005. This sequence of rather harsh reforms that were perceived as a break with the traditional social policy approach to labor market problems provoked broad public unrest (Konle-Seidl, Eichhorst, and Grienberger-Zingerle, 2007). While Hartz IV constitutes a dramatic change of the unemployment benefit and social assistance schemes, Hartz I-III addressed the organizational structure of public employment services, altered many existing active labor market programs, introduced some new schemes, and in general aimed at activating the unemployed and stimulating labor

\footnotetext{
${ }^{3}$ Named after the chairman Peter Hartz who was heading the commission (Bundesministerium für Wirtschaft und Arbeit, 2003)
} 
demand by deregulating the labor market. In the next subsections we will briefly discuss the most relevant changes for our research question.

\subsection{Unemployment Benefits and Social Assistance}

A major part of the above mentioned Hartz reforms involved the system of unemployment compensation. Prior to the reforms, Germany had a system of income protection which was based on three pillars: 1) unemployment benefits, 2) unemployment assistance and 3) social assistance. We will first briefly describe these three elements in order to allow for comparisons with the new system. A detailed description of the unemployment insurance system in Germany and its changes over time is given in Konle-Seidl, Eichhorst, and Grienberger-Zingerle (2007).

Unemployment benefits (UB, Arbeitslosengeld) provided earnings-related income replacement for a limited duration of 6-32 months if the unemployed had been in employment covered by social insurance for at least 12 months. The legal basis for UB was the Social Code III (SC III, Sozialgesetzbuch III). The replacement rate of UB was dependent on family status, while the duration was dependent on age and previous employment duration. Unemployed persons with at least one child were entitled to $67 \%$ of net remuneration and $60 \%$ otherwise. Unemployment benefit claims were based on an employment record and provided benefits proportional to prior earnings within the reference period. Individual means or needs were not taking into account. The maximum duration of unemployment benefits varied between 6 and 32 months (see Table 2). Workers who have been employed less than 12 months within the last 7 years before entering unemployment were not entitled for unemployment benefits whereas with 12 months worked a claim of 6 months was generated. The claims rose proportionally to the number of months in employment. However, several discontinuities with respect to age existed. For someone aged below 45 years the maximum entitlement period was 12 months (given that he/she was employed for at least 24 months), whereas people above 45 (and below 47) could claim up to 18 months. Further discontinuities were built in at 47 years (up to 22 months), 52 years (up to 26 months) and 57 years (up to 32 months). The benefits were funded by employer and employee contributions and administered by the FEA which was traditionally also in charge of implementing active labor market policies.

After the entitlement period of unemployment benefits had expired, unemployed individuals were eligible for, in principle, unlimited and means-tested unemployment assistance (UA, Arbeitslosenhilfe). These benefits were still earnings-related 
Table 2: Maximum Duration of Unemployment Benefit - Before and After the Hartz Reforms

\begin{tabular}{|c|c|c|c|c|c|}
\hline $\begin{array}{l}\text { Length of Benefit } \\
\text { Entitlement } \\
\text { (in months) }\end{array}$ & $\begin{array}{c}\text { Age } \\
\text { (in years) }\end{array}$ & $\begin{array}{l}\text { Months worked } \\
\text { in last } 7 \text { years }\end{array}$ & $\begin{array}{l}\text { Length of Benefit } \\
\text { Entitlement } \\
\text { (in months) }\end{array}$ & $\begin{array}{c}\text { Age } \\
\text { (in years) }\end{array}$ & $\begin{array}{l}\text { Months worked } \\
\text { in last } 3 / 5 \text { years }\end{array}$ \\
\hline \multicolumn{3}{|c|}{ Prior to the Hartz Reforms } & \multicolumn{3}{|c|}{ February 1, 2006 - February 28, 2008} \\
\hline 6 & - & 12 & 6 & - & 12 \\
\hline 8 & - & 16 & 8 & - & 16 \\
\hline 10 & - & 20 & 10 & - & 20 \\
\hline 12 & - & 24 & 12 & - & 24 \\
\hline 14 & 45 & 28 & 15 & 55 & 30 \\
\hline 16 & 45 & 32 & 18 & 58 & 36 \\
\hline 18 & 45 & 36 & \multicolumn{3}{|c|}{ Since March 1, 2008} \\
\hline 20 & 47 & 40 & 6 & - & 12 \\
\hline 22 & 47 & 44 & 8 & - & 16 \\
\hline 24 & 52 & 48 & 10 & - & 20 \\
\hline 26 & 52 & 52 & 12 & - & 24 \\
\hline 28 & 57 & 56 & 15 & 50 & 30 \\
\hline 30 & 57 & 60 & 18 & 55 & 36 \\
\hline 32 & 57 & 64 & 24 & 58 & 48 \\
\hline
\end{tabular}

Source: Social Code III ( $\$ 117$ et seq.)

(57\%/53\% replacement rate with/without children) and provided income support for unemployed people who had some prior employment experience but had become long-term unemployed. In contrast to UB, the UA was granted for an unlimited period (as long as individuals were available for the labor market) and funded by the Federal budget, i.e., by general taxation. This scheme was also implemented by the FEA. Recipients of unemployment assistance in principle had access to similar active labor market schemes as UB recipients. This distinction becomes important when we discuss the reformed system later on.

Finally, the social assistance (SA, Sozialhilfe), provided basic income protection on a means-tested and flat-rate basis for all German inhabitants. This assistance was independent of employment experience but conditional on not having other resources from earned income, other social benefits or family transfers. Therefore, social assistance was a safety net for unemployed with either no employment experience or unemployment benefit/assistance claims that did not match the guaranteed minimum income. Konle-Seidl, Eichhorst, and Grienberger-Zingerle (2007) note that means-testing was harsher in the social assistance scheme (compared to the UA scheme) and every job was considered acceptable. Social assistance was funded by the municipalities that were also responsible for reintegrating recipients into the labor market through specific active measures. A fairly rudimentary labor 
market policy — called "Help to Work" — scheme was available and operated by the municipalities with a considerable scope of discretion. There was no entitlement to integration measures by the Federal Employment Agency (Konle-Seidl, Eichhorst, and Grienberger-Zingerle, 2007) and even if capable of work, many of these needy persons were not registered as unemployed with the FEA (Bernhard, Gartner, and Stephan, 2008).

With the beginning of 2005 the Social Code II (SC II, Sozialgesetzbuch II) came into force with some major changes in the system: most importantly, the former unemployment assistance and social assistance were replaced by a single means-tested replacement scheme for needy unemployed job-seekers and their household members. The new scheme - unemployment benefit II (UB-II, Arbeitslosengeld II) - is tax-financed and covers people either in need and able to work but not entitled to unemployment benefits - from now on called unemployment benefits I (UB-I, Arbeitslosengeld I) - or after UB-I has expired. The amount of UB-II does not depend on former income and needy job-seekers and their household members are predominately registered as unemployed and may receive employment services (different from those for UB-I recipients). For UB-I recipients the most drastic change concerned the duration of benefit entitlement (see Table 2). The maximum duration was cut down to 24 months (only available for people aged at least 58 years and having worked for at least 48 months in the last five years before becoming unemployed). Initially, the reductions were even sharper before they were loosened again due to political unrest. Between February 1, 2006 ${ }^{4}$ and February 28, 2008 only two discontinuities were in place: for people aged at least 55 years the maximum duration was set to 15 months (with 30 months of employment before) and 18 months (with at least 36 months of employment).

The Hartz reforms (and especially Hartz $I V$ ) radically changed the German system of wage-related welfare. The new UB-II scheme has a dual aim: on the one hand, it was designed to prevent poverty; on the other it did not secure previous living standards. Thus, for those having received social assistance before, the new legislation actually allows them to receive marginally more money and access to job employment services (Konle-Seidl, Eichhorst, and Grienberger-Zingerle, 2007). For former recipients of UA the level of transfer payment decreased. Apart from its social policy objective, the aim of this reform was to lower unemployment but also to ease the burden of taxation and non-wage labor costs by reducing benefit

\footnotetext{
${ }^{4}$ Even though the SC II came into force in 2005, the changes concerning unemployment benefits became effective only on February 1, 2006.
} 
Table 3: The Old and the New Unemployment Benefit System

\section{Old System (Until 2004)}

New System (Since 2005)

Arbeitslosengeld (unemployment insurance benefit): funded through contributions, earnings-related, limited duration

Arbeitslosenhilfe (earnings-related unemployment assistance): tax-funded, earnings-related, meanstested, infinite duration

Arbeitslosengeld I (UB-I): funded through contributions, earnings-related, limited duration

Grundsicherung (Basic income scheme for needy jobseeker/ SGB II))

Consisting of

a) Arbeitslosengeld II (UB-II): tax-funded, meanstested, flat rate, after expiry of UB-I (and temporary supplement), infinite duration (integration of "Arbeitslosenhilfe" and "Sozialhilfe" for people capable of working) but stronger principle of activation b) Sozialgeld (social allowance) for kids below the working age of 15 living in a household of an UB-II recipient

Sozialhilfe (social assistance): taxfunded, meanstested, flat rate, infinite duration

Social assistance: means-tested, tax-funded, flat rate, infinite duration (SGB XII)

Consisting of

- Grundsicherung fur Erwerbsgeminderte und im Alter:

for those working age people above 18 years permanently not capable of working and for needy persons above 65 years

- Hilfe zum Lebensunterhalt: Help to overcome special situations in life (illness, care etc)

Source: Konle-Seidl, Eichhorst, and Grienberger-Zingerle (2007)

dependency. The major lever to achieve this goal was the shortening of individual unemployment spells through accelerated job placement and more coherent activation of the beneficiaries of unemployment insurance benefits and unemployment or social assistance. Less generous benefits for long-term unemployed, stricter job suitability criteria and more effective job placement and active labor market schemes were the instruments to achieve this goal. Table 3 summarizes the most relevant changes (Konle-Seidl, Eichhorst, and Grienberger-Zingerle, 2007). We will discuss the "activation" elements of these reforms in Section 3.3.

Finally, it is also worth noting that the organizational structure of labor market policies has been changed within the reforms. The administration of the new services for needy job-seekers is mostly conducted jointly by the Federal Employment Agency and by local municipalities. However, 69 municipalities opted out of this cooperation and provide all services for needy job-seekers on their own (Optierende Kommunen). This exception was made in order to allow local municipalities more discretion in tackling the problem of long-term unemployment. The Public Employ- 
ment Services (PES) are now organized in two branches: (1) a tax-funded branchbased on the Social Code II - for needy employable job-seekers and their households and (2) an insurance-funded branch-based on the Social Code III—for job-seekers who receive unemployment benefits I or have not yet qualified for unemployment benefits I (Bernhard, Gartner, and Stephan, 2008). Konle-Seidl (2008) and Stephan and Zickert (2008) discuss aspects of the new governance of employment services.

\subsection{Pensions, Early Retirement, and Disability}

Germany has one of the most generous public pay-as-you-go (PAYGO) pension insurance systems of the world providing pensions to all private and public sector dependent employees with the exception of civil-servants and self-employed. ${ }^{5}$ It leads to high effective replacement rates and low effective retirement ages. Through a long reform process, the system has been gradually updated and we will discuss its key elements briefly in this section. One major aspect will be the different ways of transitions into early retirement; Börsch-Supan and Wilke (2004) provide an extensive overview of the mentioned issues.

The public pension system in Germany is often characterized as a three pillar scheme: the first pillar - the public retirement insurance (PRI, Gesetzliche Rentenversicherung) - comprises the elements of the core system (old-age pension, disability pension and survivor benefits). It is laid down in the Social Code VI (Sozialgesetzbuch VI) and covers about $85 \%$ of the German work force including those public sector workers that are not civil servants. About $70 \%$ of the budget of the public retirement insurance is financed by matching contributions of employers and employees. In 2009, the mandatory contribution rate amounted to $19.9 \%$ of the first $€ 5,400$ of the monthly gross income (upper earnings threshold, Beitragsbemessungsgrenze) in former West Germany. ${ }^{6}$ The remaining part of the budget is financed by subsidies of the federal government (27.8\% in 2008). The second pillar includes the occupational and the subsidized pension scheme. Many companies provide occupational pensions (Betriebsrenten) to their employees including: pensions funds (Pensionsfonds), retirement income insurance (Rentenkassen), direct insurances (Direktversicherungen), direct pension assurances (Pensionszusagen), and benevolent funds (Unterstützungskassen). These forms differ in terms of taxation and possible ways of subsidies from the government (see Kortmann, 2008). In 2007, roughly $64 \%$ of all

\footnotetext{
${ }^{5}$ Self-employed can voluntarily contribute to the system.

${ }^{6}$ In former East Germany, the upper earnings threshold amounts to $€ 4,550$ (see Bundesministerium für Arbeit und Soziales, 2008, for details).
} 
employees eligible for social security contributions contributed to an occupational pension plan. Finally, the third and last pillar contains elements of private pension plans, such as portfolios, real assets and private pensions that are not subsidized.

The average retirement age in 2007 was 60.8 years for men and 60.6 years for women in Germany. Even though this constitutes an increase of 1.5 years for men and 0.4 years for women compared to the average retirement age in 1998 (Deutsche Rentenversicherung Bund, 2008), it still lies well below the current statutory retirement age of 65 years. Furthermore, as consequence of the demographic change towards an ageing society, the old-age dependency ratio is increasing steeply. ${ }^{7}$ Clearly, this is seriously threatening the German PAYGO pension system (along with the negative effects of early retirement) because fewer workers have to finance the benefits of more recipients. Recognizing these problems in the early 1990s led to a series of reforms between the years 1992 and 2007 which we will describe briefly later on. Before we do so, we will discuss the different benefit types in the PRI.

The public insurance system provides old-age pensions for workers aged 60 and older, disability pensions for workers below age 60 and survivor benefits for spouses and children. Additionally, the system allows for early retirement through different mechanisms mainly using the public transfer system. Old-age pensions are strictly work related, computed by a specific pension formula on a lifetime basis and adjusted for the type of pension and retirement age. In terms of the benefit level, the old-age pension has long been characterized by a very high replacement rate (Nettorentenniveau): a legally defined standard retiree (Eckrentner) at age 65 with a 45-year earnings history and average lifetime earnings received about $70 \%$ of his pre-retirement net income (Börsch-Supan and Wilke, 2004). However, the replacement rate has declined to roughly $68 \%$ in 2005 and has become less generous since 2004 due to changes in the taxation law (Alterseinkünftegesetz). Survivor benefits are paid to the surviving spouse in case of death of her husband/his wife if he/she had paid mandatory contributions to the pension system for at least five years. The benefit level amounts to $55 \%$ of the husband's/wife's applicable pension for spouses aged 45 years and older or if children live in the household, and $25 \%$ otherwise.

Disability benefits for individuals with limited abilities to work were initially financed by the Federal Employment Agency as an income replacement bound for

\footnotetext{
${ }^{7}$ This is a measure of the age structure of the population and relates to the number of individuals that are likely to be "dependent" on the support of others for their daily living to the number of those individuals who are capable of providing such support (OECD, 2006a, p. 42). In Germany, the ratio is projected to increase from 0.3 in 2007 to 0.55 through the year 2035 (Börsch-Supan and Wilke, 2007, p.7).
} 
medical impairment. As of 2001, there are two possible options. First, people who are not capable of working under regular labor market conditions due to health conditions are eligible to a full-benefit pension (Rente wegen voller Erwerbsminderung). ${ }^{8}$ They must verify having paid mandatory social security contributions for at least three out of the previous five years. Second, the weaker option applies to individuals who are still able to work more than three hours a day (Rente wegen teilweiser Erwerbsminderung). However, if no vacancies for the worker's specific job description are available, the first option applies (Börsch-Supan and Wilke, 2004, p. 13). After reaching the statutory retirement age of 65 , the disability pension is converted in both cases into the regular old-age pension. Since age was not an entrance requirement this pension scheme proved to be an attractive pathway into early retirement (Arnds and Bonin, 2002, pp. 18-19).

In 2005, about 6.7 million people were severely disabled in Germany, which corresponds to $8 \%$ of the total population. Labor market participation of people with disabilities is still low; in 2006 the unemployment rate of people with severe disabilities amounted to $16.6 \%$ (cf. Bundesagentur für Arbeit, 2007). To overcome this, there exists a wide range of rehabilitation and re-training arrangements for disabled people. According to the Social Code IX (Sozialgestzbuch IX), they have the right to claim four different types of benefits: medical rehabilitation (Leistungen zur medizinischen Rehabilitation), work rehabilitation and work assistance (Leistungen zur Teilhabe am Arbeitsleben), benefits for securing one's livelihood (Unterhaltssichernde und andere ergänzende Leistungen), and individual integration support (Eingliederungshilfe). Another element that is supposed to encourage labor force participation of disabled people is laid down in the second part of Social Code IX (Schwerbehindertenrecht). Accordingly, businesses with 20 employees or more are enforced to recruit at least $5 \%$ of their staff from individuals with disabilities. Those businesses who fail to fulfil their quotas need to pay fines (Ausgleichsabgaben) for each workplace supposed to be occupied by a disabled worker. The Social Code IX also requires that enterprises have to adjust their premises in order to suit the needs of disabled workers. Furthermore, it provides legislation which protects the disabled against discrimination in recruitment and employment as well as unfair dismissal (Lechner and VazquezAlvarez, 2003).

The German pension system allows for certain ways of transitions into early retirement. In general, individuals may retire voluntarily at any time between 63 and

\footnotetext{
${ }^{8}$ The "capability of working" is defined as being able to work three hours per day in the foreseeable future under usual labor market conditions.
} 
the full statutory retirement age which is currently the age of 67 (we will discuss the most recent reform later on). As compensation for the longer duration of pension payments, however, the pension reform in the late 1990s reduced the pension by $0.3 \%$ for each month of commencement of the pension before the age of 65 years (Bonin, 2009). The aggregate pension loss can still be quite substantial given the conditional life expectancy of above 15 years at retirement age (Berkel and Börsch-Supan, 2003).

From 1957 to 2005, the German pension system allowed for transitions into early retirement in the case of an unemployment spell of at least one year. The relevance of this early retirement scheme had grown steadily, first of all mostly because of the high and persistent long-term unemployment rate in Germany. Additionally, the social policy shift at the beginning of the 1970s aimed at taking surplus labor out of the market by active and passive policies contributed to it's importance (Arnds and Bonin, 2002). Today, this pathway to early retirement is not possible anymore for individuals born after 1952 .

Old-age part-time (Altersteilzeit) constitutes a different possibility to reduce labor supply. Individuals, who completed the age of 55 and have been subject to social security contributions for at least three out of the previous five years may: (1) reduce their volume of employment by half, receiving a reduced salary from their employer or (2) continue working full-time and retire fully but earlier afterwards. ${ }^{9}$ The latter option is know as the "block model" and the general and legal framework of this arrangement is laid down in the Old-Age Part-Time Employment Act (Altersteilzeitgesetz). It is subject to regulations within collective bargaining agreements between employers and employees. Individuals taking the first option of old-age part-time receive $70 \%$ of their former net wage and the employer contributes to the pension system on the basis of $90 \%$ of the employee's full-time employment compensation (Arnds and Bonin, 2002, p. 21). ${ }^{10}$ Since its introduction in 1996, old-age part-time schemes have become more and more important. In 2006, men on average entered into one of the old-age part-time schemes at age 57.6 (women at 57.0 years). Indi-

\footnotetext{
${ }^{9}$ The old-age part-time scheme is usually accompanied by an early entry into retirement since individuals may still obtain reduced old-age pensions after completion of their old-age part-time arrangement. For the birth cohorts until 1945, a reduced old-age pension is possible starting from age 60 . However, this retirement age has been gradually lifted to 63 years between 2006 and 2008 . For birth cohorts 1952 and younger it is not possible anymore to retire before the age 65 within the old-age part-time scheme (Wanger, 2009)

${ }^{10}$ Since the employee in old-age part-time receives a wage that is (at least) $20 \%$ higher than the one he would receive for "normal" part-time, the employer "augments" the part-time salary by a certain (tax-free) amount (Aufstockungsbetrag). This amount is paid by the FEA in case the employer hires an unemployed individual or an apprentice in consequence of the part-time agreement.
} 
viduals in old-age part-time may still obtain reduced old-age pensions at age 60 if they were born before 1945. However, this retirement age had been gradually lifted from 60 to 63 between the years 2006 and 2008. Moreover, for the cohorts 1952 and younger it is not possible anymore to enter the early-retirement scheme due to the recent reforms which we will describe now (see Wanger, 2009, for an extensive description).

The first element of the 1992 reform was the indexing of pensions to net instead of gross wages and salaries. As a result, the benefits have implicitly been reduced due to the increase of taxes and social security contributions lowering the net relative to gross wages. The second major element was the introduction of an actuarial adjustment for early retirement and a gradual uplift of the statutory retirement age for all pension types to 65 years (see Börsch-Supan and Wilke, 2004, for more details). The actuarial adjustment for early retirement consisted in a reduction of the pension by $0.3 \%$ for each month of commencement of the pension before the age of 65 years as compensation for the longer duration of pension payments (Bonin, 2009). Many elements of the 1992 reform were revoked after the change of government in 1998 and are therefore not discussed here. However, the gradual change of eligibility ages from 60 to 65 for women and unemployed individuals was not revoked and even accelerated so that it has been already fully implemented by 2005 . This basically made early-retirement (without reduction) due to part-time schemes and long-term unemployment de facto impossible for individuals born after 1952 (Bourcarde, 2006). The Riester Reform ${ }^{11}$ was ratified in 2001 and was a new pension reform act constituting a major change in the system by partially substituting the PAYGO financed pensions by funded pensions. Since January 1, 2002, individuals compulsory insured in the PRI may - in addition to the first pillar statutory pension scheme - obtain supplementary private pensions with capital coverage. These pensions are subsidized by the federal government (Riester Rente). Although these supplementary pensions are not compulsory they are supposed to counteract the decline in public pensions. A second noteworthy element of the reform aimed at stabilizing the contribution rates: the indexing of pensions was reversed back to gross wages and the law was changed so that the contribution rate is kept below $20 \%$ until 2020 and $22 \%$ until 2030 (Social Code VI $\S 154$ (3)). In the 2004 reform a sustainability factor was introduced into the pension adjustment formula ( $R V$-Nachhaltigkeitsgesetz). This factor mainly accounts for demographic changes by considering the ratio between pensioners and contributors to the system (Sachverständigenrat zur Begutachtung

\footnotetext{
${ }^{11}$ The reform was named after the former labor minister Walter Riester.
} 
der Gesamtwirtschaftlichen Entwicklung, 2004). The last major amendment to the pension system took place in 2007. The statutory retirement age of 65 will be gradually lifted to 67 years. In detail, starting from the year 2012 and with the birth cohort of 1947 the age limit will be increased by one month per year and birth cohort. This means that the birth cohort of 1958 will have to work up to the age of 66 . The mandatory retirement age of 67 will be reached by the year 2029 for all birth cohorts born from 1964 onwards (Bonin, 2009).

\subsection{Active Labor Market Policies and Activation Measures}

Germany has a long tradition in the provision of active labor market policies and there exist several ALMP programs supporting the integration of unemployed persons into the labor market (see inter alia Caliendo and Steiner, 2005; Bernhard, Hohmeyer, Jozwiak, Koch, Kruppe, Stephan, and Wolff, 2008, for comprehensive overviews). However, with the Hartz reforms a shift has been made towards active measures that require proactive behavior of the unemployed and promote their direct integration into regular employment. Jacobi and Kluve (2007) describe the Hartz reforms as a tripartite reform strategy aimed at (1) improving labor market services and policy measures in terms of effectiveness and efficiency, (2) activating the unemployed based on the principle of "rights and duties" (Fördern und Fordern) and finally (3) stimulating labor demand by deregulating the labor market. Under the first category falls the re-organization of local employment offices, giving more discretion to local offices and introducing market forces in the provision of training and other services, e.g., voucher systems for placement services (Vermittlungsgutschein) and training measures (Bildungsgutschein). The former is given to individuals who could not be placed by the public employment service within six weeks of unemployment allowing them to choose alternative private placement services. With the latter one, individuals can choose between different private providers of training measures and pay for their services with the voucher. The Public Employment Service is now also enabled to outsource services, e.g., placement via temporary work in staff service agencies (Personal Service Agentur). Furthermore, an improved targeting of active measures and a better allocation of resources were additional aims. This was mainly done by profiling customers into four types and addressing their needs accordingly. Finally, it was also agreed upon to conduct rigourously scientific evaluations of all the measures (see Jacobi and Kluve, 2007, for more detials).

The second part of the strategy is the most relevant for our analysis here trying 
Table 4: Entries in Selected Labor Market Programs (2000-2008, in 1,000)

\begin{tabular}{|c|c|c|c|c|c|c|c|c|c|c|c|c|c|}
\hline & \multirow[t]{2}{*}{2000} & \multirow[t]{2}{*}{2001} & \multirow[t]{2}{*}{2002} & \multirow[t]{2}{*}{2003} & \multirow[t]{2}{*}{2004} & \multicolumn{2}{|c|}{$2005^{a}$} & \multicolumn{2}{|c|}{$2006^{a}$} & \multicolumn{2}{|c|}{$2007^{a}$} & \multicolumn{2}{|c|}{$2008^{a}$} \\
\hline & & & & & & II & III & II & III & II & III & II & III \\
\hline \multicolumn{14}{|l|}{ Entries into program } \\
\hline Wage subsidy & 152 & 127 & 188 & 183 & 157 & 60 & 73 & 105 & 113 & 125 & 123 & 120 & 130 \\
\hline Further vocational training & 523 & 442 & 455 & 255 & 185 & 65 & 66 & 102 & 144 & 140 & 201 & 196 & 260 \\
\hline Public job creation I $(A B M s)$ & 318 & 246 & 215 & 179 & 161 & 62 & 16 & 62 & 16 & 50 & 16 & 60 & 6 \\
\hline Public job creation II (1-Euro-Jobs) & - & - & - & - & - & 630 & - & 741 & - & 703 & - & 696 & - \\
\hline Short-term training & 485 & 551 & 865 & 1064 & 1188 & 410 & 483 & 444 & 534 & 480 & 520 & 496 & 587 \\
\hline Contracting-out placement services ${ }^{b}$ & - & - & - & - & 635 & 273 & 153 & 149 & 153 & 113 & 121 & 176 & 254 \\
\hline Start-up subsidy & - & - & - & 97 & 171 & - & 91 & - & $43^{c}$ & - & - & - & - \\
\hline Bridging allowance & 93 & 96 & 125 & 159 & 184 & - & 157 & - & $108^{d}$ & - & 176 & - & - \\
\hline New start-up subsidy: Soical Code III & - & - & - & - & - & - & - & - & - & - & 126 & - & 119 \\
\hline New start-up subsidy: Soical Code II & - & - & - & - & - & - & - & 32 & - & 30 & - & 25 & - \\
\hline
\end{tabular}

a) Programs covered by Social Code II (without municipalities opting out of the cooperation with the Public Employment Service) and III

b) Figures are available since 2004, while different variants started already in 1998 respectively 2002

c) Entries from January to July

d) Entries from January to November

Source: Federal Employment Agency

to activate the unemployed and integrate them in the first labor market. The new policy mix targets explicitly job seekers who want to end their unemployment spell in a self-responsible way. To this end, the reform re-designed integration subsidies, introduced new forms of wage subsidies, start-up subsidies and jobs with reduced social security contributions. Emphasis was shifted away from public job creation schemes which have been proven not to be effective (see, e.g., Caliendo, Hujer, and Thomsen, 2008b).

Table 4 contains the number of entries in different programs for the years 20002008; from 2005 onwards distinguished by persons falling under Social Code III and needy job-seekers under Social Code II. The most important programs covered by Social Code III are contracting-out, start-up subsidies, short-term training and further vocational training. We are discussing some of these elements in the following and provide some preliminary evaluation results in Section 4. The most important programs covered by Social Code II are public job creation schemes (Hohmeyer and Wolff, 2007) and short-term training (Wolff and Jozwiak, 2007). Contractingout placement services to private providers (Bernhard and Wolff, 2008), further vocational training and targeted wage subsidies are less often used, but are still important instruments.

A good example of the policy shift within the reforms is the introduction of a new start-up subsidy. In the years 2003-2006 turning unemployment into self-employment became a major focus of German active labour market policy. Whereas the Federal Employment Agency funded only 37,000 business start-ups by formerly unemployed individuals in 1994, the number reached a peak with above 350,000 entries in 2004. 
This increase was driven, among other things, by a new program known as the 'startup subsidy' (SUS, Existenzgründungszuschuss), which was directly introduced as part of the Hartz reforms. Unemployed individuals could then choose between this and a second program, the 'bridging allowance' (BA, Überbrückungsgeld), which was already implemented in the late 1980s. In 2004, 17.2\% of ALMP resources were allocated to these measures helping unemployed individuals to end their unemployment spell in a proactive behavior. Furthermore, integration into regular employment by wage subsidies when hiring hard-to-place workers was also made easier by simplifying the eligibility conditions of integration subsidies. Additionally some elements were introduced intending to "make work pay", e.g., subsidies to social security contributions (SSC) if the job qualifies as a Mini-Job. The main objective of this part of the reform was to provide positive work incentives for people with low earnings potential by subsidizing social security contributions and allowing unemployed individuals to top up their benefits (up to 165 Euro per month). Labor income up to 400 Euro was exempted from employees' SSC and these jobs were labeled Mini-Job (or marginal employment); for earnings between 401 and 800 Euro a degressive subsidy was introduced (and henceforth called Midi-Job). This reform included three major changes compared to pre-reform regulations. First, the maximum amount for earnings exempted from SSC was increased from 325 to 400 Euro. Second, the previous maximum hours restriction (15 hours per week) was abolished. Third, income up to 400 Euro per month from a mini-job held as a secondary job, which was fully taxable before the reform, was now exempted from SSC and income tax. This is in line with several European countries introducing in-work benefits, tax credits, or subsidies to social security contributions (SSC) for working individuals. Examples are the Working Family Tax Credit (WFTC) in the UK (see, e.g., Blundell, Duncan, McCrae, and Meghir, 2000) and the French Prime Pour l'Emploi (see, e.g., Stancanelli, 2005). Finally, the Hartz reforms also introduced sanction elements in order to effectively monitor the unemployed's search activities and personal efforts to return into the regular labor market. Any offer of suitable work needs to be accepted where the definition of suitable work was broadened. Furthermore, benefit receipt is tied to the availability for work and program participation. As part of the closer monitoring process, individual action plans (Eingliederungsvereinbarung) were introduced, too. These plans result from the profiling process of the unemployed, listing the services that will be provided to the job-seeker as well as the job-seeker's obligation towards the employment agency, e.g., in terms of job search activities and participation in labor market programs. If the unemployed individual does not comply with this plan, 
she can be threatened with sanctions in the form of temporary benefit reductions (Jacobi and Kluve, 2007). The Social Code II also emphasizes activation policies. One of these policies is a workfare program, which was implemented at a large scale: the work opportunity program in which participants receive their unemployment benefit II and additionally one to two Euros per hour worked (called One-EuroJob, see Hohmeyer and Wolff, 2007, for an extensive discussion). One-Euro-Jobs are designed for employable needy persons aged between 15 and 64 years. Since they are subordinate to regular employment, vocational training and other active labor market programs, they can be seen as a measure of last resort. That given, specific target groups for this program are hard-to-place unemployed or those who are distant to the labor market. One-Euro-Jobs should enhance employability as well as reemployment chances. Another application of this program is the usage as a willingness-to-work test where no specific target group is defined and unemployed with rather good labor market chances are also likely to participate (Hohmeyer and Jozwiak, 2008). The tasks carried out in One-Euro-Jobs have to be of public utility and additional in the sense that they would not be completed without the subsidy. In many dimensions the design of this program is similar to classical job-creation schemes which have been heavily used in the 1990s and early 2000s. There have been many studies evaluating the effects of job-creation schemes; finding mainly negative or at best insignificant effects for participating individuals (see, inter alia, Caliendo, Hujer, and Thomsen, 2008a,b). We will briefly present some first evaluation results for the One-Euro-Jobs in Section 4.

\subsection{Parental Leave Benefit}

Germany is known to have one of the lowest fertility rates among Western European countries and there is not much hope to expect a substantial increase over the current rate of 1.4 any time soon (Spiess and Wrohlich, 2006). Moreover, the labor force participation of mothers with young children in Germany is very low compared to other EU member states (cf. OECD, 2006b). Although these trends have been observed during the last decades, the German public has only recently begun discussing these issues. The underlying reasons for this unfortunate mix-low fertility and low participation - can be seen as a result of a combination of various institutional arrangements preventing mothers from working full-time, e.g., missing child-care facilities, and rather strong and persistent preferences of (West-)German parents to give care to young children at home (Bonin, 2009). Additionally, one 
should note that young mothers' labor force participation crucially depends on the child's age: whereas only one third of the mothers with a child under three years of age were employed in Germany in 2005 (33\%) already more than half of those having a child aged 3-5 years actively participated in the labor force (56\%). The highest employment rate of $71 \%$ was achieved by mothers with children aged 10-14 years (Statistisches Bundesamt, 2005). In order to reverse these trends, the German government passed a reform of the parental leave benefit system (PLB, Elterngeld) in line with the Scandinavian model. The core piece of the reform is the replacement of the existing means-tested parental leave benefit by a wage-dependent benefit for the period of one year (Spiess and Wrohlich, 2006). The PLB came into effect in 2007 and replaced the means-tested preceding benefit (Erziehungsgeld). It is provided for up to 14 months to parents of children born on January 1, 2007 or later. ${ }^{12}$ The benefit replaces $67 \%$ of the average net income earned in the 12 months prior to the birth of the child for the parent staying at home. ${ }^{13}$ The parent is eligible for benefit if he or she does not work full-time, which is defined as 30 hours per week. Besides the aim of increasing labor market participation of mothers with young children and fostering involvement in child care of fathers, the reform explicitly intended to increase fertility rates (Tamm, 2009).

In 2009, the PLB was evaluated by the Federal Ministry for Families concerning the short-term effects of the introduction of the benefit on employment behavior of parents with a new-born child (Bundesministerium für Familie, Senioren, Frauen und Jugend, 2009, conducted by the RWI). The study was based on a mail survey of a sample of parents $(\mathrm{N}=1,595)$ whose child was born in April 2007 and who had applied for and received the parental leave benefit. The study finds that the majority of young mothers resumed employment after having received parental leave benefit. In detail, about $13 \%$ of all women took up part-time work again after 6 months. 12 months after the child's birth one third of all young mothers (31\%) were already reemployed. After 18 months the share added up to $39 \%$ reaching $42 \%$ after 24 months. However, two third of the women state that the infrastructure of child care services is insufficient in their region (Bundesministerium für Familie, Senioren, Frauen und Jugend, 2009, p. 44). Along with the request of better in-firm child care possibilities, these results indicate that the parental leave benefit only develops its full impact in combination with better early child care services and more flexible models of working hours for women.

\footnotetext{
${ }^{12} \S 4(1)$ Gesetz zum Elterngeld und zur Elternzeit (BEEG).

${ }^{13}$ The monthly benefit ranges from $€ 300$ for low-income parents up to a maximum rate of $€ 1,800$.
} 


\subsection{Income Splitting as a Source for Reduced Labor Supply}

The number of hours worked by employed persons in Germany is comparatively low by international standards. This is mainly due to a high share of secondaryearners (most often women) working only part-time with very few hours (OECD, 2008). It is often argued that the current system of income taxation creates fiscal disincentives for secondary earners because Germany allows for "income splitting" between married partners (Ehegattensplitting, § 32a (5) Einkommensteuergesetz). The taxable income of both spouses is cumulated and the sum is then split in half. The income tax is calculated by applying the tax function to the resulting amount and doubled in a third step to determine the tax liability of the couple. As a result, the amount of the income tax of a married couple may be lower than the tax the same couple would have to pay if both spouses were taxed individually according to the principle of separate taxation (Schlick, 2005). This results in a "splitting effect" and is seen by critics as a main reason for the relatively low labor force participation rate of married women in Germany. The secondary earner has to earn enough to offset the marriage gain, which is caused by the "splitting effect", before she contributes to family income and marginal earnings of the second wage earner are hit by a high tax rate (Gustafsson, 1992). ${ }^{14}$

Therefore, moving to a system of individual taxation has been occasionally proposed by experts (OECD, 2008, p. 76). Steiner and Wrohlich (2004) use a microsimulation model to estimate potential labour supply effects of a shift from joint taxation to individual taxation. The authors find that the female participation rate would increase by around 4.85 percentage points and the total number of hours worked by women would rise by $11.40 \%$. However, many public finance experts maintain the contrary by considering that there is no marriage gain from joint taxation at all. They rather argue that joint taxation is a logical consequence of the progressive tax system in Germany given the normative rule that taxation should be neutral with respect to the distribution of incomes within the household (Schlick, 2005, p. 319). Moreover, taxing persons on a purely individual basis may come into conflict with the constitutional law in Germany. ${ }^{15}$

In a recent paper Dearing, Hofer, Lietz, Winter-Ebmer, and Wrohlich (2007)

\footnotetext{
${ }^{14}$ As soon as the wife starts contributing to the family income, the "splitting effect" becomes smaller. The more she contributes the smaller is the gain from joint taxation compared to a nonmarried couple. The marginal tax rate on second-earners is therefore higher than for singles.

${ }^{15}$ In 1957, the German constitutional court (BVerfGE, Bundesverfassungsgericht) ruled that married couples should not be disadvantaged relative to non-married couples and that an equal share of the total household earnings belongs to each person in a marriage (BVerfGE 6, 55).
} 
compare two countries - Austria and Germany - in terms of work incentives created by the tax and transfer system and childcare institutions. Both countries are quite similar in many institutional aspects but differ in their detailed characteristics concerning the tax system: while in Germany married spouses are taxed jointly and are eligible for full income splitting, Austria has a system of individual taxation. Moreover, Austria has a much more generous parental leave benefit system. Hence, it is interesting to note that labor force participation rates of mothers in Austria and Germany are similar; however, full-time employment rates are much higher among Austrian mothers. In order to figure out to what extent these differences can be attributed to differences in the tax-transfer system, the authors estimate structural labor supply models for both countries and then interchange two important institutional characteristics of the two countries: the definition of the tax unit within the personal income tax and the parental leave benefit scheme. The results show that differences in mothers' employment patterns can partly be explained by the different tax systems: individual taxation in Austria leads to lower marginal tax rates for secondary earners and increases labor supply incentives. The authors argue that labor force participation of German mothers would rise considerably if Germany would introduce Austria's income tax and parental leave benefit characteristics.

\section{The Effects of the Reforms}

\subsection{Evaluation of the Hartz Reforms (up to 2006)}

One of the nice features of the Hartz reforms from a scientific point of view was the implementation of a mandatory evaluation of all the relevant measures. Different research consortia were involved in analyzing the effects of the three reform tiers: (1) improving labor market services and policy measures in terms of effectiveness and efficiency, (2) activating the unemployed based on the principle of "rights and duties" (Fördern und Fordern) and finally (3) stimulating labor demand by deregulating the labor market. This allows us to draw on evaluation results based on rich individual data which were not available for research in Germany before. We will present some selected results for the second tier, a full documentation can be found in Bundesregierung (2007); Eichhorst and Zimmermann (2007) and Jacobi and Kluve (2007) summarize the results. As already mentioned above, the Hartz reforms involved a shift towards more active measures by redesigning integration and wage subsidies, introducing a new start-up subsidy and jobs with reduced social 
security contributions. We will present some exemplary evaluation results.

Table 5: Effects of Hartz Reforms (until 2006)

\begin{tabular}{|c|c|c|c|c|}
\hline \multirow{2}{*}{\multicolumn{2}{|c|}{ Tier/Measure }} & \multicolumn{2}{|c|}{ Evidence } & \multirow[t]{2}{*}{ Reform Effect } \\
\hline & & before & after & \\
\hline \multicolumn{5}{|c|}{ 1a. Placement services } \\
\hline & $\begin{array}{l}\text { Placement-voucher } \\
\text { (Vermittlungsgutschein) }\end{array}$ & $\mathrm{n} / \mathrm{a}$ & 0 & $\begin{array}{l}0 \text { No significant effect on re-employment proba- } \\
\text { bility. }\end{array}$ \\
\hline & $\begin{array}{l}\text { Assignment to private placement } \\
\text { providers }^{a} \text { (Beauftragung Dritter) }\end{array}$ & $\mathrm{n} / \mathrm{a}$ & 0 & $\begin{array}{l}0 \text { No significant effect on re-employment proba- } \\
\text { bility. }\end{array}$ \\
\hline & Placement via temporary work (PSA) & $\mathrm{n} / \mathrm{a}$ & - & $\begin{array}{l}\text { - PSAs reduce the employment probability of } \\
\text { participants. }\end{array}$ \\
\hline 1b. & Training & $\begin{array}{l}\mathbf{0} \text { older } \\
\text { stud- } \\
\text { ies/ } \\
(+) \\
\text { more } \\
\text { recent } \\
\text { studies }\end{array}$ & + & $\begin{array}{l}+ \text { Exit rate into employment increased, locking- } \\
\text { in effects reduced. }\end{array}$ \\
\hline
\end{tabular}

\begin{tabular}{|c|c|c|c|c|c|}
\hline $1 c$. & Public job creation $(A B M)$ & - & $(-)$ & $\overline{(+}$ & $\begin{array}{l}\text { Measure remains detrimental after the reform. } \\
\text { Magnitude of negative effect is decreasing. Im- } \\
\text { pact on "employability" unclear. }\end{array}$ \\
\hline $2 \mathrm{a}$. & $\begin{array}{l}\text { Wage subsidies to employers } \\
\text { (Eingliederungszuschüsse) }\end{array}$ & $(+)$ & + & + & $\begin{array}{l}20-50 \text { percentage points higher probabil- } \\
\text { ity of regular employment post-treatment. } \\
\text { Extents of windfall gains unclear. }\end{array}$ \\
\hline $2 \mathrm{~b}$. & $\begin{array}{l}\text { Start-up } \\
\text { (Überbrückungsgeld, "Ich- } A G ")\end{array}$ & $(+)^{b}$ & + & + & $\begin{array}{l}\text { Subsidy significantly reduces risk of } \\
\text { unemployment (decreasing over time). } \\
\text { Some windfall beneficiaries exist. }\end{array}$ \\
\hline \multirow[t]{3}{*}{$2 c$. } & $\begin{array}{l}\text { Employment with reduced social } \\
\text { security contributions }\end{array}$ & & & & \\
\hline & Mini-Jobs & $\mathrm{n} / \mathrm{a}$ & + & $\begin{array}{l}+ \\
(-)\end{array}$ & $\begin{array}{l}\text { Reform caused large increase in em- } \\
\text { ployees in minijobs }(+1.8 \text { million }) \text {. } \\
\text { Inflow from unemployment low. Incidence of } \\
\text { intra-enterprise displacement cannot be ruled } \\
\text { out. }\end{array}$ \\
\hline & Midi-Jobs & $\mathrm{n} / \mathrm{a}$ & $(+)$ & $\begin{array}{l}(+) \\
(-)\end{array}$ & 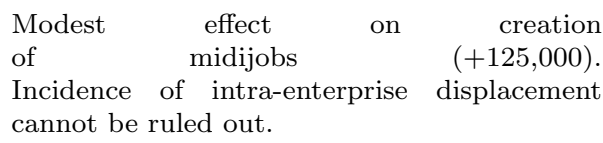 \\
\hline 3a. & Temporary work deregulation & $\mathrm{n} / \mathrm{a}$ & + & + & $\begin{array}{l}23,700 \text { additional employees in temporary } \\
\text { work } 6 \text { months after reform (short-term). } \\
\text { Deregulation widely acclaimed. }\end{array}$ \\
\hline $3 \mathrm{~b}$. & $\begin{array}{l}\text { Fixed-term contracts for older } \\
\text { workers }\end{array}$ & $\mathrm{n} / \mathrm{a}$ & 0 & 0 & No significant effect. \\
\hline
\end{tabular}

Notes: Labour market effects: + positive, (+) modestly positive, 0 zero, $(-)$ modestly negative, - negative

a) Already since early 2002 .

b) Pre-reform evidence on bridging allowance only.

Source: Jacobi and Kluve (2007)

Jaenichen and Stephan (2007) analyze the effectiveness of targeted wage subsidies, covering a share of labor costs and paid to employers for a fixed period of time, for hard-to-place workers, who took up subsidized employment during the second quarter of 2002. They concentrate on the subsidy variant for unemployed with 
severe problems of reintegration, e.g., long-term unemployed or disabled persons. Using propensity-score matching methods they show that wage subsidies may increase the employment prospects of supported workers to a considerable amount. For previously unemployed individuals, three years after the start of the program, the share in regular employment is $25-42 \%$ higher in the treatment group than in the matched control group. Baumgartner and Caliendo (2008), Caliendo (2009) and Caliendo, Künn, and Wießner (2009) analyze the effects of the two available startup subsidies helping unemployed workers to become entrepreneurs. They base their analysis on administrative and survey data and follow individuals for up to five years after the start of the subsidy. Given the relatively stable participant structure in the BA program since the introduction of the SUS one can argue that the SUS attracts a different 'clientele' for self-employment (see Caliendo and Kritikos, 2009, for more details on that). In general it can be stated that participants in SUS are less qualified (when compared to BA participants), and that this program is more frequently used by women. Using a conditional difference-and-differences estimator the authors estimate the effectiveness of both programs relative to nonparticipation. The results indicate that both programs are successful: the unemployment rate of participants at the end of the observation period is considerably lower, the probability of being in self-employment and/or paid employment as well as the personal income is higher for participants. Rinne, Uhlendorff, and Zhao (2008) study the role of training vouchers and caseworkers in public training programs. They use a rich administrative data set and apply matching and regression methods to measure the effect of the introduction of the training vouchers and more selective criteria on participants (which was also part of the Hartz reforms). Besides estimating the overall reform effect, they isolate the effect induced by changes in the composition of program participants due to stricter selection by the caseworkers (selection effect) from the effect based on the introduction of vouchers (voucher effect). They find a slightly positive impact of the reform and their decomposition results suggest that the selection effect is, if at all slightly negative, and that the voucher effect increased both the employment probability and earnings of the participants. RWI et. al (2005) analyze the effects of the introduction of Mini- and Midi-Jobs from a macroeconomic perspective. They show that the introduction of both types of jobs introduced a significant increase in the number of employees in this income range. However, the largest part of this increase is due to re-definitions (caused by the altered threshold from 325 to 400 Euro) and secondary jobs, i.e., where individuals already in regular employment take up a Mini-Job as secondary employment. Moreover, the incidence 
of intra-enterprize displacement cannot be ruled out. Caliendo and Wrohlich (2010) use a natural experiment to analyze the effects of the Mini-Job reform on labor supply and do not find positive results on overall labor supply either; exceptions are students and secondary job holders. Hence, this part of the reform does not seem to have been overly successful.

Table 5 ist taken from Jacobi and Kluve (2007) and summarizes the evaluation results with respect to the different tiers. In addition, the authors also distinguish between pre- and post-reform evaluation results. For most of the instruments and initiatives no pre-reform results are available, either because the instrument has been newly introduced or because the previously available data were not sufficient. Several new measures - like placement vouchers or contracting out - do not display significant effects, some traditional measures like training and job creation schemes improve due to the reform. For training this is mainly due to the reduced locking-in effect, for job creation schemes it means that the effects are not as detrimental for participants as before. Jacobi and Kluve (2007) conclude that based on the comprehensive evaluation of the Hartz reforms involving more than 20 research institutions, rich evidence is produced giving the general impression that the effectiveness of measures has improved modestly. The new strategy with more emphasis on activating elements - like start-up or wage subsidies - seems to be a promising policy mix. Since the evaluation of the Hartz reforms were all finished by 2006, the results can only be preliminary at most covering medium- but rather only short-term effects.

\subsection{Evaluation of the Hartz Reforms (since 2006)}

The effects of the final parts of the Hartz reforms (and especially Hartz $I V$ ) have not been included in the first evaluations mentioned above but were part of a second large evaluation project which is still ongoing. We are using this subsection to present some more recent results on selected elements of the reforms targeted at needy job-seekers. Bernhard, Gartner, and Stephan (2008) estimate the average effect of targeted wage subsidies paid to employers for a limited period of time on the subsequent labor market prospects of participating needy job-seekers (who are entitled to UB-II). Based on propensity score matching their results show that wage subsidies had in fact large and significant favorable effects: 20 months after taking up a subsidized job, the share of persons in regular employment is nearly 40 percentage points higher for participants (when compared to nonparticipants). Estimated effects on the shares not unemployed and the which is not longer receiving 
UB-II are slightly smaller. Wolff and Jozwiak (2007) estimate for a sample of UB-II recipients the effects of their participation in short-term training programs. They analyze a period shortly after the start of Hartz $I V$, i.e., just after the reform of the means-tested benefit system which aimed at activating employable people in needy households was introduced. Short-term training programs intensively target such persons. The authors study whether the program has an impact on the regular employment rate of the treated and also differentiate between programs within companies and classroom training. They find that the former program which establishes a contact to an employer, has a considerable impact on the regular employment rate of participants. Both programs tend to be less effective in particular for people aged younger than 25 years than for others. This may reflect that the programs are also a tool to avoid that young adults are registered as unemployed for longer than three months. Bernhard and Wolff (2008) analyze the effectiveness of the temporary assignment of needy job-seekers to private placement services (contracting out) with respect to three outcomes: employment, unemployment and benefit receipt. They use administrative data and apply propensity score matching to construct the control group. The time period under consideration is a period shortly after introduction of UB-II. Since hard-to-place job-seekers usually need more effort to be placed into a job it is an interesting question whether groups of people with different a priori employment probabilities benefit to a different extent from an assignment to a private placement service. The authors analyze several subgroups separated by sex, age, migration background, occupational training and time since the last job. Their results suggest that in some cases the assignment to private providers is relatively more effective for groups of job-seekers who are rather hard to place. Despite positive employment effects for some subgroups, however, their results imply that the assignment to private providers is generally ineffective and in some subgroups counterproductive regarding the goal of avoiding unemployment and benefit receipt. Hohmeyer (2009) analyzes the workfare part of the Hartz reforms, i.e., the One-Euro-Jobs. With roughly 700,000 means-tested benefit recipients participating per year this is a huge program (see again Table 4). Using administrative data for participants who entered the program in spring 2005 she investigates medium-term effects of the program and the association between flexibility in design and effect heterogeneity. First, effects of different types of One-Euro-Jobs (according to planned duration and weekly working hours) compared to non-participation/waiting are estimated and second, program types are compared directly by pairwise matching to disentangle selection and program effects. The results show that lock-in effects 
are larger for participation with a longer planned duration, whereas this is not the case for more intensive programs in terms of working hours. In the medium term, One-Euro-Jobs do not generally increase the employment prospects for men in East Germany beyond two years after program start and longer and more intensive participation even decreases employment prospects. In West Germany, One-Euro-Jobs in general increase the employment chances and longer participation leads to slightly better employment opportunities roughly two years after program start. The initial advantage of short participation decreases over time.

Wolff and Nivorozhkin (2008) study the effect of participation in a new business start-up scheme for needy unemployed people in Germany which was also introduced at the beginning of 2005. The authors use participants who enter the program between February and April 2005 and use matching to construct a control group. One shortcoming of the data is that they do not provide information on self-employment (beyond participation in the program). Therefore, they estimate the impact of program participation on the outcomes "neither being registered as unemployed nor as a job-seeker" and "no receipt of UB-II". The estimates imply that even by the time when nearly no participant receives the start-up subsidy anymore treatment reduces considerably the proportion of registered job-seekers and of means-tested benefit recipients among the treated. Moreover, there is no substantial variation of these effects over different population groups. Schneider (2008) analyzes the effect of benefit sanctions on the reservation wage of sanctioned unemployment benefit II recipients; where benefit sanctions were tightened with the introduction of UB-II in 2005. She uses propensity score matching and a survey dataset of UB-II recipients in the first year after its introduction. For the identification of the effect, the study relies on rich individual data and the rather unsystematic sanctioning process in the starting months after introduction. The timing of the sanction is explicitly considered by estimating the effects for the first four quarters of UB-II receipt in 2005. The main result is that there was no significant effect of sanctions on the reservation wages of sanctioned UB-II recipients. A side result is that sanctioned UB-II recipients were not more likely to be employed at the time of their interview either. Both results are robust to various matching estimators, estimation specifications and to the timing of the UB-II sanction. Table 6 summarizes the evaluation results of these programs targeted at needy UB-II recipients. Overall, some slightly modest short-term effects can be identified and it will be interesting to examine mediumand long-term impacts. 


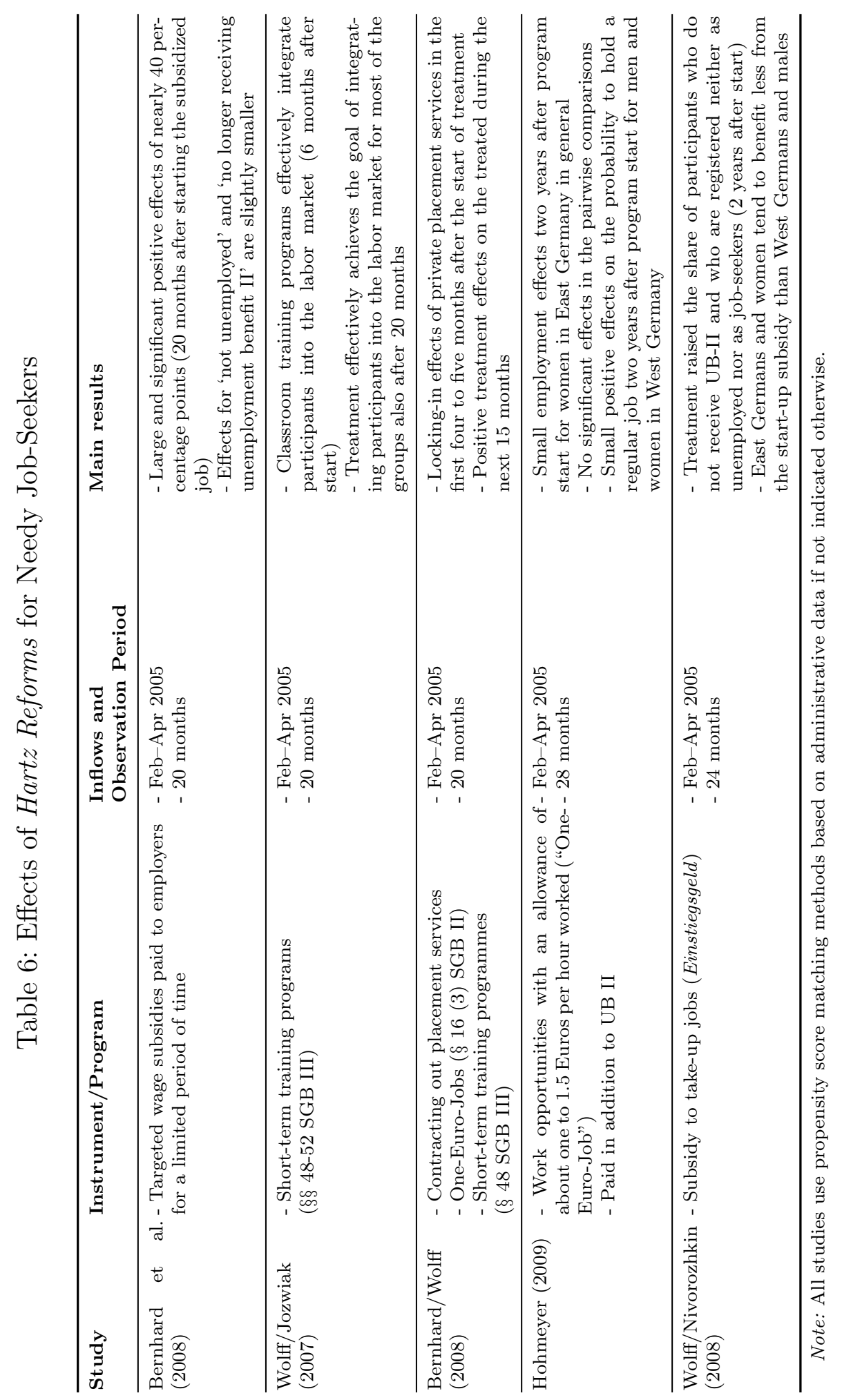




\subsection{Ex-Ante Evaluation of Benefit Reforms on Labor Sup- ply}

In Germany there also exists a large bulk of literature using behavioral microsimulation and computable general equilibrium (CGE) models to evaluate the effects of tax and transfer reforms before their implementation. These ex-ante evaluations are especially useful if different reform scenarios need to be judged. Given the complex tax and benefit system in Germany, this is not an easy task. While CGE models take into account various interdependencies and adjustments on several markets, microsimulation models (MSM) usually focus on the household side of the economy. However, the latter models allow for more heterogeneity and a more detailed mapping of the complex tax-benefit system. Not only "first-round" effects (i.e. income changes) are calculated, but also behavioral responses of individuals or households are taken into account ("second-round" effects). Tax-benefit models with labor supply responses are the prime example for behavioral microsimulation models (Creedy and Duncan, 2006). We are going to briefly describe three studies in this subsection; two aimed at analyzing the effects of the Hartz reforms, one looking at the new parental leave benefit.

Arntz et al. (2007) analyze labor supply and redistribution effects of the Hartz $I V$ reforms by using a microsimulation model of the Centre for European Economic Research (ZEW) based on data of the German Socio-Economic Panel (GSOEP). In terms of income distribution, they find a small decline of income inequality within the overall population. However, households with high unemployment benefits previous to the reform are negatively affected and experience a decline in their income. In contrast, households with many children and low income in the status quo were declared as "winners" of the reform. Moreover, the study finds varying labor supply effects depending on income loss or gain. Households who experience a decline in their income partly compensate their loss with a higher labor force participation. The reverse effect applies to households gaining income. Franz et al. (2007) combine a MSM with a CGE model to quantify labor supply effects of the introduction of UBII. The CGE model incorporates important features of the German labor market in which wages are determined by sectoral wage bargaining between labor unions and firms. Their microsimulation results yield overall negative employment effects after the introduction of UB-II. Hence, the desirable positive effects of the Hartz IV reform can not be verified ex-ante in their partial equilibrium analysis. Using the CGE model they found a decline in gross wages for low-qualified workers, whereas high- 
qualified workers experienced a slight increase. Subsequently, the unemployment rate decreases for both groups - the decrease being stronger for low-qualified workers since they experienced a reduction in gross wages - and yielded an overall positive employment effect. Spiess and Wrohlich (2006) estimate potential implications of the PLB using a microsimulation model. The first-round effects of their analysis indicate that on average couples and single parents in all income groups profit from the reform. Moreover, computed costs of the reform show that the reform does not appear to be as costly as previously had been asserted in the public debate. The results of the behavioral responses (second-round effects) show that the reform would not change the participation rate of mothers in the first year after the child was born. The same result applies to fathers as well. In the second year after the child's birth, however, the model results show a $12 \%$ increase in working hours for mothers. Furthermore, the participation rate increases from $36 \%$ to $39 \%$. In light of these results, the authors also mention that the labor market participation of young mothers is crucially linked to the provision of child care services.

\section{Conclusions}

Germany has undergone some major labor market reforms in the last decade. The reforms touched the core elements of the labor market, including active and passive labor market policies, the organizational structure of the labor offices as well as the pension system. As a general goal the reforms were aimed at activating people by increasing their incentives to take up work, but also introducing the principle of "rights and duties". The Hartz reforms were initiated in 2001/2002 and the speed and depth of the reforms is quite remarkable, especially when having the picture of Germany as a "frozen welfare state" in mind. Three reform tiers could be distinguished: (1) improving labor market services and policy measures in terms of effectiveness and efficiency, (2) activating the unemployed based on the principle of "rights and duties" and finally (3) stimulating labor demand by deregulating the labor market. Since Germany is also known to have one of the lowest fertility rates among Western European countries in combination with a very low labor force participation among mothers with young children, an additional reform was introduced in 2007. The core piece of this reform is the replacement of the previously existing means-tested parental leave benefit by a wage-dependent benefit for the period of one year; accompanied by the provision of more child-care facilities for children under three years of age. Most interesting - at least from a scientific point 
of view - is the new tendency in Germany to accompany all the mentioned reforms with mandatory evaluations. This allows us now to draw on rich individual data and conduct rigorous scientific evaluations to judge the effects of these reforms. The aim of this paper was twofold. First, we gave a brief overview of the most relevant income support systems and their recent reforms and second, we discussed evaluation results of the recent reforms where already available. Overall, it is fair to say that Germany seems to be on the right track with these reforms. The effectiveness and efficiency of labor market instruments has been increased and the incentives for unemployed individuals to take up work have been improved. While the labor market reforms were surrounded by huge political unrest, the reforms concerning the pension system have been less controversial, but also quite considerable. What has been a one tier system for nearly a century is now (becoming) a multi-pillar system where the public insurance only plays a smaller role. The success in both reform areas is threatened with the current financial crisis. Rising non-wage labor costs will hamper employment creation, which in the end, is the missing link for a truly successful reform story. The current financial crisis will also have a negative impact on all pillars of the public retirement insurance, where pensions for current and future retirees will be lower compared to the pre-crisis situation (Börsch-Supan, Gasche, and Wilke, 2009). Additionally, Germany is currently also tackling the issue of low female labor force participation (especially among young mothers). The reform of the parental benefit leave aims to increase the labor market participation of parents with young children and even though it is too early to draw any conclusions here, preliminary results seem promising (Kluve and Tamm, 2009). What is not tackled yet, are the disincentives due to the tax system and it is also questionable whether this will be approached anytime soon. Looking back at the last decade of reforms in Germany one can get the impression that policy makers tend to underestimate the political risk associated with reforms and the period needed to generate positive results in terms of more jobs and lower unemployment. The reforms implemented between 1998 and 2005 have been crucial for the labor market, but caused also substantial political unrest which ended in a change of government. It remains to be seen, how future governments will react to worsened economic conditions in light of these experiences. 


\section{References}

Alphametrics / ApplicA (2009): "Trends in Inactivity and Unemployment," Study undertaken for the Swedish Ministry of Employment.

Arnds, P., And H. Bonin (2002): "Frühverrentung in Deutschland: Ökonomische Anreize und institutionelle Strukturen," Discussion Paper 666, IZA.

Arntz, M., M. Clauss, M. Kraus, R. Schnabel, A. Spermann, and J. Wiemers (2007): "Arbeitsangebotseffekte und Verteilungswirkungen der Hartz IV Reform," Forschungsbericht 10/2007, IAB.

Baumgartner, H., and M. Caliendo (2008): "Turning Unemployment into SelfEmployment: Effectiveness of Two Start-Up Programmes," Oxford Bulletin of Economics and Statistics, 70(3), 347-373.

Berkel, B., AND A. BÖrsch-Supan (2003): "Renteneintrittsentscheidungen in Deutschland: Langfristige Auswirkungen verschiedener Reformoptionen," Discussion Paper 31-2003, MEA.

Bernhard, S., H. Gartner, and G. Stephan (2008): "Wage Subsidies for Needy Job-Seekers and Their Effect on Individual Labour Market Outcomes after the German Reforms," Discussion Paper 3772, IZA.

Bernhard, S., K. Hohmeyer, E. Jozwiak, S. Koch, T. Kruppe, G. Stephan, and J. Wolff (2008): "Aktive Arbeitsmarktpolitik in Deutschland und ihre Wirkungen," Forschungsbericht 2/2008, IAB.

Bernhard, S., AND J. WolfF (2008): "Contracting out placement services in Germany. Is assignment to private providers effective for needy job-seekers?," Discussion Paper 5/2008, IAB.

Blundell, R., A. Duncan, J. McCrae, and C. Meghir (2000): "The Labour Market Impact of the Working Families Tax Credit," Fiscal Studies, 21(1), 75-104.

Bonin, H. (2009): "15 Years of Pension Reform in Germany," Discussion Paper 06-035, ZEW.

Börsch-Supan, A., M. Gasche, and B. Wilke (2009): "Auswirkungen der Finanzkrise auf die Gesetzliche Rentenversicherung, ihre Beitragszahler und ihre Rentner," meastudies09, MEA.

Börsch-Supan, A., And C. Wilke (2007): "Szenarien zur mittel- und langfristigen Entwicklung der Anzahl der Erwerbspersonen und der Erwerbstätigen in Deutschland," Discussion Paper 153-2007, MEA.

Börsch-Supan, A., And C. B. Wilke (2004): "The German Public Pension System: How it was, how it will be," Working Paper 10525, NBER.

Bourcarde, K. (2006): "Die Reform der Gesetzlichen Rentenversicherung," IWSStudie: Sozialreformen seit 1989, 2, 16-24.

Bundesagentur für Arbeit (2007): Arbeitsmarkt $200 \%$.

Bundesministerium Für Arbeit und Soziales (2008): Rentenversicherungsbericht 2008.

Bundesministerium für Familie, Senioren, Frauen und Jugend (2009): Evaluationsbericht Bundeselterngeld- und Elternzeitgesetz 2009. 
Bundesministerium für Wirtschaft und Arbeit (2003): "Moderne Dienstleistungen am Arbeitsmarkt," Bericht der Kommission zum Abbau der Arbeitslosigkeit und zur Umstrukturierung der Bundesanstalt für Arbeit, BMWI.

BundesRegierung (2007): "Die Wirksamkeit moderner Dienstleistungen am Arbeitsmarkt - Bericht 2006 der Bundesreigerung zur Wirkung der Umsetzung der Vorschläge der Kommission Moderne Dienstleistungen am Arbeitsmarkt," Bericht, BMAS.

Caliendo, M. (2009): "Start-Up Subsidies in East Germany: Finally, a Policy that Works?," International Journal of Manpower, 30(7), 625-647.

Caliendo, M., R. Hujer, and S. Thomsen (2008a): "Identifying Effect Heterogeneity to Improve the Efficiency of Job Creation Schemes in Germany," Applied Economics, 40(9), 1101-1122.

(2008b): "The Employment Effects of Job Creation Schemes in Germany A Microeconometric Evaluation," in Modelling and Evaluating Treatment Effects in Econometrics, ed. by D. L. Millimet, J. A. Smith, and E. Vytlacil, vol. 21 of Advances in Econometrics, pp. 381-428, Amsterdam. Elsevier.

Caliendo, M., S. KÜnn, And F. Wiessner (2009): "Die Nachhaltigkeit von geförderten Existenzgründungen aus Arbeitslosigkeit: Eine Bilanz nach fünf Jahren," forthcoming in: Journal for Labour Market Research / Zeitschrift für ArbeitsmarktForschung.

Caliendo, M., and A. Kritikos (2009): "Start-Ups by the Unemployed: Characteristics, Survival and Direct Employment Effects," Small Business Economics, DOI 10.1007/s11187-009-9208-4.

Caliendo, M., and V. Steiner (2005): "Aktive Arbeitsmarktpolitik in Deutschland: Bestandsaufnahme und Bewertung der mikroökonomischen Evaluationsergebnisse," Zeitschrift für Arbeitsmarktforschung / Journal for Labour Market Research, 38(2-3), 396-418.

Caliendo, M., and K. Wrohlich (2010): "Evaluating the German 'Mini-Job' Reform Using a Natural Experiment," forthcoming in: Applied Economics.

Creedy, J., And A. Duncan (2006): "Behavioural Microsimulation with Labour Supply Responses," Journal of Economic Surveys, pp. 1-39.

Dearing, H., H. Hofer, C. Lietz, R. Winter-Ebmer, and K. Wrohlich (2007): "Why are Mothers Working Longer Hours in Austria than in Germany? A Comparative Microsimulation Analysis," Fiscal Studies, 28(4), 463-495.

Deutsche Rentenversicherung Bund (2008): Rentenversicherung in Zeitreihen. Frankfurt.

EichHorst, W., ANd P. MARx (2009): "Reforming German Labor Market Institutions: A Dual Path to Flexibility," Discussion Paper 4100, IZA.

Eichhorst, W., and K. Zimmermann (2007): "And Then There Were Four...How Many (and Which) Measures of Active Labor Market Policy Do We Still Need?," Applied Economics Quarterly, 53(3), 243-272.

Esping-Andersem, G. (1990): The Three Worlds of Welfare Capitalism. Prcineton University Press, Princeton. 
Franz, W., N. Guertzgen, S. Schubert, and M. Clauss (2007): "Reformen im Niedriglohnsektor - eine integrierte CGE-Mikrosimulationsstudie der Arbeitsangebots- und Beschäftigungseffekte," Discussion Paper 07-085, ZEW.

Gustafsson, S. (1992): "Separate taxation and married women's labor supply - A comparison of West Germany and Sweden," Journal of Poulation Economics, 5, $61-85$.

Hohmeyer, K. (2009): "Effectiveness of One-Euro-Jobs. Do programme characteristics matter?," Discussion Paper 20/2009, IAB.

Hohmeyer, K., And E. JozWiak (2008): "Who is targeted by One-Euro-Jobs? A selectivity analysis," Discussion Paper 8/2008, IAB.

Hohmeyer, K., And J. WolfF (2007): "A fistful of Euros - Does One-Euro-Job participation lead means-tested benefit recipients into regular jobs and out of unemployment benefit II receipt?," Discussion Paper 32/2007, IAB, Nuremberg.

Jacobi, L., And J. Kluve (2007): "Before and After the Hartz Reforms: The Performance of Active Labour Market Policy in Germany," Zeitschrift für ArbeitsmarktForschung, 1, 45-64.

Jaenichen, U., and G. Stephan (2007): "The Effectiveness of Targeted Wage Subsidies for Hard-to-place Workers," Discussion paper, IAB.

Kemmerling, A., and O. Bruttel (2005): "New Politics in German Labor Market Policy?," Discussion Paper 101, WZB, Berlin.

Kluve, J., And M. Tamm (2009): “Now Daddy's Changing Diapers and Mommy's Making Her Career: Evaluating a Generous Parental Leave Regulation Using a Natural Experiment," Discussion Paper 4500, IZA.

Konle-SeidL, R. (2008): "Changes in the governance of employment services in Germany since 2003," Discussion Paper 10/2008, IAB.

Konle-Seidl, R., W. Eichhorst, and M. Grienberger-Zingerle (2007): "Activation Policies in Germany: From Status Protection to Basic Income Support," Discussion Paper 6/2007, IAB.

Kortmann, K. (2008): Situation und Entwicklung der betrieblichen Altersversorgung in Privatwirtschaft und öffentlichem Dienst 2001-2007 - Endbericht. TNS Infratest Sozialforschung.

Lechner, M., and R. Vazquez-Alvarez (2003): "The Effect of Disability on Labour Market Outcomes in Germany: Evidence from Matching," Discussion Paper 967, IZA.

Manow, P., And E. Seils (2000): "Adjusting Badly: The German Welfare State, Structural Change, and the Open Economy," in Welfare and Work in the Open Economy, ed. by F. W. Scharpf, and V. A. Schmidt, vol. 2, pp. 264-307. Oxford University Press, Oxford.

OECD (2006a): Society at a Glance 2006 - OECD Social Indicators. OECD. (2006b): Starting Strong II - Early Childhood Education and Care. OECD. (2008): OECD Economic Surveys: Germany Vol. 2008/7. OECD. 
Rinne, U., A. UhlendorfF, And Z. Zhao (2008): "Vouchers and Caseworkers in Public Training Programs: Evidence from the Hartz Reform in Germany," Discussion Paper 3910, IZA.

RWI, ISG, GISA, IWH, Burda M., KvansickA M. (2005): "Evaluation der Maßnahmen zur Umsetzung der Vorschläge der Hartz-Komission Modul 1f: Verbesserung der beschäftigungpolitischen Rahmenbedingungen und Makrowirkungen der aktiven Arbeitsmarktpolitik," Research report, BMAS.

SACHVERSTÄNDIGENRAT ZUR BEGUTACHTUNG DER GESAMTWIRTSCHAFTLICHEN ENTWICKLUNG (2004): Jahresgutachten 2004/05 - "Erfolge im Ausland - Herausforderungen im Inland".

Schlick, G. (2005): "Das Splitting-Verfahren bei der Einkommensteuerveranlagung von Ehegatten," Wirtschaftsdienst, 85, 312-319.

SCHNEIDER, J. (2008): "The effect of unemployment benefit II sanctions on reservation wages," Discussion Paper 19/2008, IAB.

Spiess, K., And K. Wrohlich (2006): "The Parental Leave Benefit Reform in Germany: Costs and Labour Market Outcomes of Moving towards the Scandinavian Model," Discussion Paper 630, DIW.

StancAnelli, E. (2005): "Evaluating the Impact of the French Tax Credit Programme, "La Prime Pour L'Emploi": A Difference in Difference Model," Working Paper, OFCE.

Statistisches Bundesamt (2005): Leben und Arbeiten in Deutschland - Sonderheft 2: Vereinbarkeit von Familie und Beruf, Ergebnisse des Mikrozensus 2005.

Steiner, V., and K. Wrohlich (2004): "Household Taxation, Income Splitting and Labor Supply Incentives - A Microsimulation Study for Germany," CESifo Economic Studies, 50(3), 541-568.

Stephan, G., and K. Zickert (2008): "Participation of unemployment benefit recipients in active labor market programs: Before and after the German labor market reforms," Discussion Paper 15/2008, IAB, Nuremberg.

TAmm, M. (2009): "The Impact of a Large Parental Leave Benefit Reform on the Timing of Birth around the Day of Implementation," Ruhr Economic Papers 98, RWI.

WANGER, S. (2009): "Altersteilzeit - beliebt aber nicht zukunftsgerecht," Kurzbericht 8/2009, IAB.

WolfF, J., And E. JozWiAK (2007): "Does short-term training activate meanstested unemployment benefit recipients in Germany?," Discussion Paper 29/2007, IAB.

WolfF, J., And A. Nivorozhkin (2008): "The effectiveness of a self-employment programme for needy unemployed people in Germany," Discussion Paper 20/2008, IAB. 